\title{
Coupling microbial fuel cells with a membrane photobioreactor for wastewater treatment and bioenergy production
}

\author{
Hei Tsun $\mathrm{Tse}^{1} \cdot$ Shuai $\mathrm{Luo}^{1} \cdot \operatorname{Jian} \mathrm{Li}^{1} \cdot \mathrm{Zhen} \mathrm{He}^{1}$
}

Received: 28 April 2016/ Accepted: 13 June 2016/Published online: 18 June 2016

(C) Springer-Verlag Berlin Heidelberg 2016

\begin{abstract}
Microbial fuel cells (MFCs) and membrane photobioreactors are two emerging technologies for simultaneous wastewater treatment and bioenergy production. In this study, those two technologies were coupled to form an integrated treatment system, whose performance was examined under different operating conditions. The coupled system could achieve 92-97\% removal of soluble chemical oxygen demand (SCOD) and nearly $100 \%$ removal of ammonia. Extending the hydraulic retention time (HRT) of the membrane photobioreactor to 3.0 days improved the production of algal biomass from $44.4 \pm 23.8$ to $133.7 \pm 12.9 \mathrm{mg} \mathrm{L}^{-1}$ (based on the volume of the treated water). When the MFCs were operated in a loop mode, their effluent (which was the influent to the algal reactor) contained nitrate and had a high $\mathrm{pH}$, leading to the decreased algal production in the membrane photobioreactor. Energy analysis showed that the energy consumption was mainly due to the recirculation of the anolyte and the catholyte in the MFCs and that decreasing the recirculation rates could significantly reduce energy consumption. The energy production was dominated by indirect electricity generation from algal biomass. The highest energy production of $0.205 \mathrm{kWh} \mathrm{m}^{-3}$ was obtained with the highest algal biomass production, resulting in a theoretically positive energy balance of $0.033 \mathrm{kWh} \mathrm{m}^{-3}$. Those results have demonstrated that the coupled system could be an alternative approach for energy-efficient wastewater treatment and using wastewater effluent for algal production.
\end{abstract}

Zhen $\mathrm{He}$

zhenhe@vt.edu

1 Department of Civil and Environmental Engineering, Virginia Polytechnic Institute and State University, Blacksburg, VA 24061, USA
Keywords Microbial fuel cell - Membrane photobioreactor - Algae separation · Bioelectricity · Wastewater treatment

\section{Introduction}

Microbial fuel cells (MFCs) are an attractive treatment concept for resource recovery from wastewater [1]. In MFCs, electrochemically active microorganisms use solid electron acceptors (e.g., anode electrodes) for decomposing organic compounds and generate electrons to reduce terminal electron acceptors (e.g., oxygen) on a cathode [2]. Various substrates including both synthetic organics and actual wastewater have been examined for electricity generation in MFCs [3]. It has been reported that electricity generation can stimulate the degradation of organic compounds, thereby making MFCs a potential approach for treating recalcitrant compounds such as petroleum hydrocarbons [4]. Nutrients like nitrogen and phosphorus are considered as the important contaminants because of their effects on eutrophication and thus must be properly removed from wastewater. However, unless nitrate is present in the influent (thus can be removed by denitrification [5]), the anaerobic condition in the anode of an MFC is not suitable for nutrient removal, because both ammonia oxidation and enhanced biological phosphorous removal will require oxygen. Appropriate design of the MFC operation can accomplish nitrogen removal via nitrification and bioelectrochemical denitrification in the cathode or transport of ammonium ions driven by electricity generation $[6,7]$; on the other hand, phosphorous removal may take advantage of high $\mathrm{pH}$ as a result of the cathode reactions for forming precipitates [8]. Nevertheless, there is a need for further exploring MFC technologies for enhanced treatment performance. 
Microalgae can effectively consume nutrients for their growth, and as a result, algal biomass can be used to produce valuable products such as biodiesel or other highvalue bioproducts $[9,10]$. Microalgae have been incorporated into MFCs for various purposes [11]. For example, algae can be used as a substrate in the anode for bioelectricity generation [12]. More interestingly, algae are employed in the cathode of MFCs for nutrient uptake and supplying dissolved oxygen to assist cathode reactions [13-15]. In an early study, a sediment type photo-MFC took advantage of the synergistic interaction between microalgae (Chlorella vulgaris) and bacteria to achieve removal of both organics and nitrogen from wastewater [16]. A new type of algal-MFC system, named integrated photobioelectrochemical systems (IPB), was developed to maximize the mutual benefits between the two processes [17]. The long-term operation of such an IPB system could achieve more than $90 \%$ organic removal, nearly $98 \%$ ammonium removal, and $82 \%$ phosphate removal, and the produced energy (combined bioelectricity and biomassconverted energy) could theoretically meet the requirement of energy consumption by this system [17]. The dominant photoautotrophs in the cathode suspension and biofilms of the IPB system were identified as cyanobacteria Leptolyngbya and green alga Acutodesmus [18]. Like many other algal-based systems, a potential problem for algalMFC systems is the separation and collection of the produced algal biomass, and this has not been studied well in the previous work.

There have been various methods for separating algal biomass from growth media but cost effectiveness represents a major challenge [19]. Membrane-based separation such as microfiltration (MF) or ultrafiltration (UF) is of strong interest because of its effective separation of algal biomass and achieving a great effluent quality when treating wastewater is a simultaneous task. Membrane separation is integrated into photobioreactors forming membrane photobioreactor [20]. Like membrane bioreactors (MBRs), membrane photobioreactors also have submerged membrane module [21] or sidestream installation [22]. When the treated wastewater was used to cultivate C. vulgaris, the membrane photobioreactor achieved a volumetrical algae productivity nearly four times that of a conventional photobioreactor, and the removal of both nitrogen and phosphorus had also been significantly enhanced [23]. The attached growth of microalgae in a membrane photobioreactor improved the algal productivity more than $140 \%$ compared to the suspended growth [24]. In addition to MF/UF, forward osmosis membrane was also used in membrane photobioreactors for extracting water from algal media with sodium chloride as a draw solute [25]. Those prior studies have demonstrated the feasibility of membrane photobioreactors for separating algal biomass and achieving good removal of major contaminants. However, in general, membrane performance such as variation of transmembrane pressure (TMP) was not reported in details.

In this study, two tubular MFCs were coupled with a membrane photobioreactor for treating a synthetic wastewater. In this coupled system, wastewater is first treated in the MFCs for organic removal and bioelectricity generation; then the MFC effluent is treated in the membrane photobioreactor for nutrient removal and algal biomass production. Compared with the IPB system that has algal growth in the MFC cathode, the separate algal bioreactor in the present system may allow more operational flexibility. For example, any changes to algal bioreactors or algal biomass harvesting will not affect the MFC operation; the drawback will be higher capital investment for a larger footprint. The specific objectives of this study were to (1) demonstrate the feasibility of the proposed system for bioenergy production and wastewater treatment; (2) investigate the effect of the extended retention time in the algal bioreactor on its performance; (3) examine the influence of a loop operation of the MFCs on the system performance; and (4) analyze energy production and consumption.

\section{Materials and methods}

\section{System setup}

The present system consisted of two identical tubular MFCs and one membrane photobioreactor (Fig. 1). The tubular MFCs were made of cation exchange membrane (CEM, Ultrex CMI7000, Membranes International, Inc., Glen Rock, NJ) with a length of $100 \mathrm{~cm}$ and a diameter of $5 \mathrm{~cm}$, and constructed according to the previous studies [26, 27]. A carbon brush was inserted into the CEM tube as an anode electrode, resulting in a liquid volume of $1.75 \mathrm{~L}$ in each MFC. The cathode electrode was a piece of carbon cloth

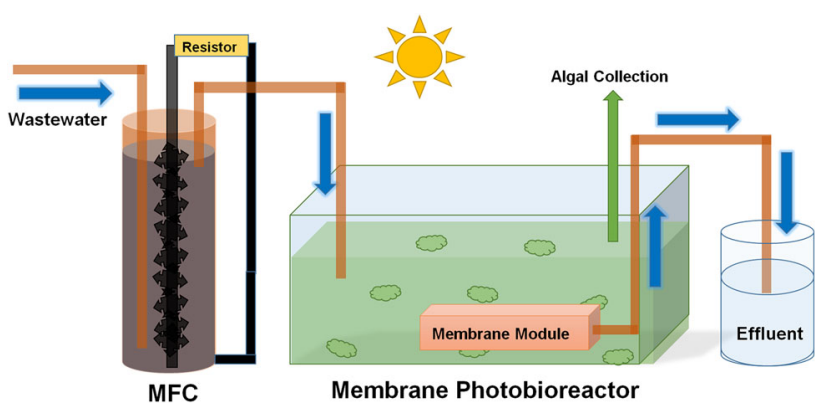

Fig. 1 The schematic of the treatment system consisting of MFCs and a membrane photobioreactor 
coated with activated carbon [28] as a cathode catalyst ( $5 \mathrm{mg} \mathrm{cm}^{-2}$ ), and the carbon cloth wrapped the CEM tube. The anode and the cathode electrodes were connected using titanium wires to an external circuit across a resistor. The membrane photobioreactor was a rectangular glass tank containing two membrane modules, each of which had thirteen 28-cm PVDF hollow fiber ultrafiltration membranes (15,000 Da, Litree Purifying Technology Co. China).

\section{System operation}

The system was operated at room temperature of $\sim 20{ }^{\circ} \mathrm{C}$. The anodes of the MFCs were fed with a synthetic solution containing (per L of tap water): sodium acetate $0.25 \mathrm{~g}$; $\mathrm{NH}_{4} \mathrm{Cl} 0.15 \mathrm{~g} ; \mathrm{NaCl} 0.50 \mathrm{~g} ; \mathrm{MgSO}_{4} 0.02 \mathrm{~g} ; \mathrm{CaCl}_{2} 0.02 \mathrm{~g}$; $\mathrm{NaHCO}_{3} 0.50 \mathrm{~g} ; \mathrm{KH}_{2} \mathrm{PO}_{4} 0.01 \mathrm{~g} ; \mathrm{K}_{2} \mathrm{HPO}_{4} 0.02 \mathrm{~g}$; and $1 \mathrm{~mL}$ trace elements [29]. The anolyte was recirculated at $200 \mathrm{~mL} \mathrm{~min}^{-1}$ and the catholyte was recirculated at $120 \mathrm{~mL} \mathrm{~min}^{-1}$, unless stated otherwise. The synthetic solution first flowed through the MFC anodes and then was fed into the membrane photobioreactor. The final effluent was extracted from the membrane module. The anode of the MFC was inoculated with anaerobic sludge from Peppers Ferry Regional Wastewater Treatment Plant (Radford, VA, USA), and the membrane photobioreactor was inoculated with green algae collected from a local water pond (mixture of algae and bacteria). In the experiment of MFC loop operation, the MFC anode effluent flowed over the MFC cathodes functioning as the catholyte, before being supplied to the membrane photobioreactor. The catholyte was recirculated at $60 \mathrm{~mL} \mathrm{~min}{ }^{-1}$ during the loop operation. The hollow fiber membrane module was operated in a 4-min working/1-min relaxation mode. The flow rate was controlled by peristaltic pump. The hydraulic retention time (HRT) in the membrane photobioreactor was adjusted in some tests by enlarging the liquid volume, instead of changing the flow rate.

\section{Measurement and analyses}

The voltage of the MFCs was recorded every 5 min by a digital multimeter (2700, Keithley Instruments, Inc., Cleveland, OH, USA). The current and power density was normalized to the anode liquid volume. The $\mathrm{pH}$ was measured using a benchtop $\mathrm{pH}$ meter (Oakton Instruments, Vernon Hills, IL, USA). The concentration of chemical oxygen demand (COD) was measured using a COD digester and a colorimeter according to the manufacturer's instructions (Hach Company, Loveland, CO, USA). The concentrations of ammonia, nitrate, and phosphorous were measured using a colorimeter (DR 890, Hach Company). Transmembrane pressure (TMP) was recorded manually.
Energy recovery was evaluated by normalized energy recovery (NER) in $\mathrm{kWh} \mathrm{m}^{-3}$, which is a key parameter to assess the amount of energy that could be generated for treating one cubic meter of wastewater [30, 31]. The theoretic energy consumption by the pumping system (for recirculating the electrolytes) was estimated using the following equation [32]:

$P=\frac{Q \gamma E}{1000}$,

where $P$ is power requirement $(\mathrm{kW}), Q$ is flowrate $\left(\mathrm{m}^{3} \mathrm{~s}^{-1}\right), \gamma$ is $9800\left(\mathrm{~N} \mathrm{~m}^{-3}\right)$, and $E$ is head loss $\left(\mathrm{m} \mathrm{H}_{2} \mathrm{O}\right)$.

\section{Results and discussion}

\section{Determination of MFC internal resistance}

The MFCs were started as two electrically independent reactors, each of which had its own electrical circuit. After current generation became stable, polarization tests were performed to obtain the key parameters of the MFCs (Fig. 2). The open circuit voltage (OCV) of the MFC-1 (which was the first to receive the synthetic solution) was $0.60 \mathrm{~V}$, lower than $0.67 \mathrm{~V}$ of the MFC-2; this was likely due to the intrinsic difference in MFC reactors, for example, the loading rate of the cathode catalysts and difference in the anode electrode (e.g., surface area and density of carbon fibers). The maximum power output of the MFC-1 was $4.4 \mathrm{~mW}$ (or $2.5 \mathrm{~W} \mathrm{~m}^{-3}$ ), which was also lower than $5.5 \mathrm{~mW}$ (or $3.1 \mathrm{~W} \mathrm{~m}^{-3}$ ) of the MFC-2. However, the MFC-1 generated short-circuit current of $30.0 \mathrm{~mA}$ (or 17.1 $\mathrm{A} \mathrm{m}^{-3}$ ), higher than $27.3 \mathrm{~mA}$ (or $15.6 \mathrm{~A} \mathrm{~m}^{-3}$ ) from the MFC-2, likely related to less concentration polarization (diffusion limitation) in the MFC-1 by having priority for substrate supply. The internal resistance calculated from polarization curves was $21.6 \Omega$ in the MFC- 1 and $24.1 \Omega$ in the MFC-2. After the startup period, the two MFCs were electrically connected in parallel. Serial connection was not adopted here because the same liquid stream flowing through two MFCs could create a short-circuit condition. With the parallel connection, OCV is governed by the MFC with lower OCV, and in fact, the OCV of the paralleled MFC was $0.57 \mathrm{~V}$, slightly lower than that of the MFC-1. The short circuit current of the paralleled system was $60.0 \mathrm{~mA}$, which is the sum of the current from the two MFCs, but current density of $17.1 \mathrm{~A} \mathrm{~m}^{-3}$ was similar to that of the individual MFCs. The maximum power output of the parallelled MFC system was $8.5 \mathrm{~mW}$ (or $2.4 \mathrm{~W} \mathrm{~m}^{-3}$ ), at which the internal resistance was $10 \Omega$. Therefore, the MFC system was operated with an external resistor of $10 \Omega$ in the following experiments. 

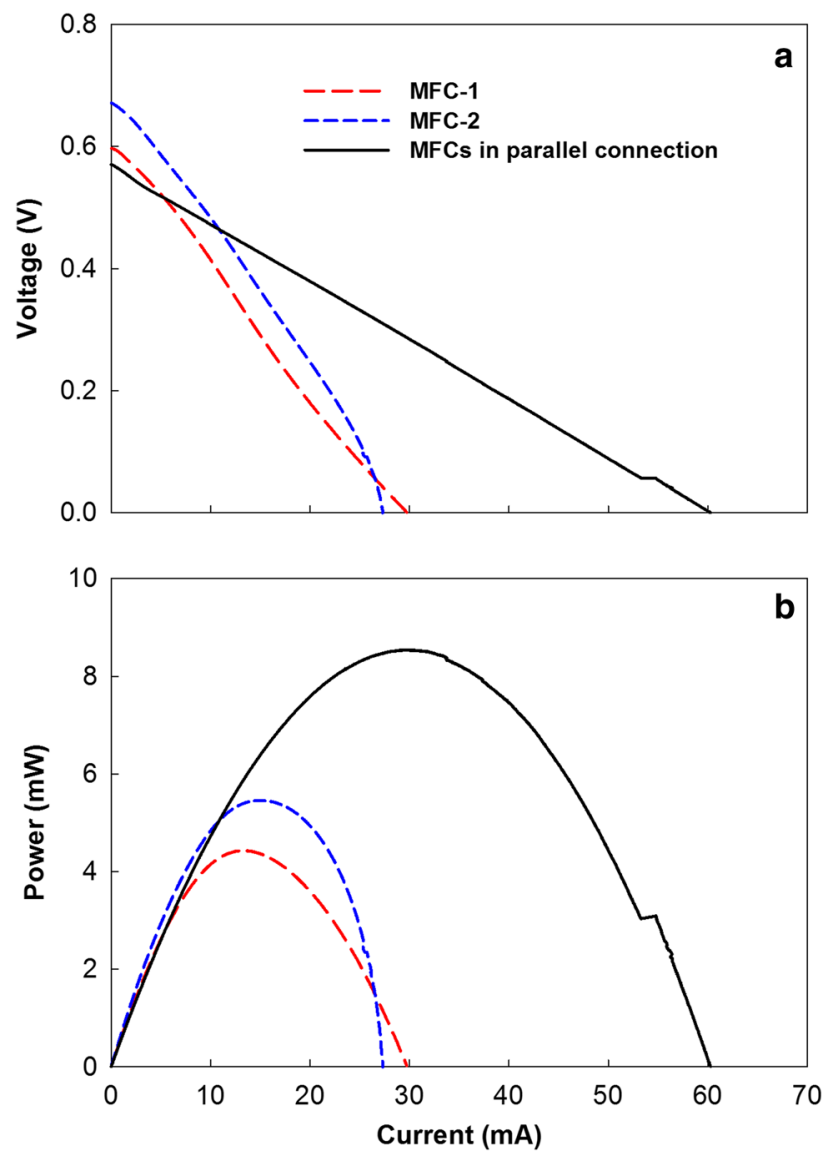

Fig. 2 Polarization tests of the individual MFCs and the parallelconnected MFCs: a voltage curves; and b power curves

\section{The treatment performance}

The MFC system was hydraulically linked to the membrane photobioreactor, and the key performance parameters such as removal of organic compounds and nutrient were examined. The influent contained soluble COD (SCOD) of $186.0 \pm 14.9 \mathrm{mg} \mathrm{L}^{-1}$, which was reduced to $71.1 \pm$ $23.3 \mathrm{mg} \mathrm{L}^{-1}$ after the MFC treatment, representing a removal efficiency of $62 \%$ (Fig. 3). The membrane photobioreactor further decreased the SCOD concentration to $15.7 \pm 10.5 \mathrm{mg} \mathrm{L}^{-1}$ (in the membrane permeate), another $30 \%$ removal. Overall, the system achieved $92 \%$ of SCOD removal. The system also exhibited great performance in ammonium removal. The influent ammonium concentration was $36.7 \pm 3.0 \mathrm{mg} \mathrm{N} \mathrm{L}^{-1}$, which decreased to $12.3 \pm 1.0 \mathrm{mg} \mathrm{N} \mathrm{L}^{-1}$ after the MFCs and further down to $1.2 \pm 1.5 \mathrm{mg} \mathrm{N} \mathrm{L}^{-1}$ in the membrane permeate. Ammonium removal in the MFCs was mostly due to ammonium ion transport across the CEM driven by both electricity generation and concentration gradient [8]. The removed ammonium was converted to ammonia in the

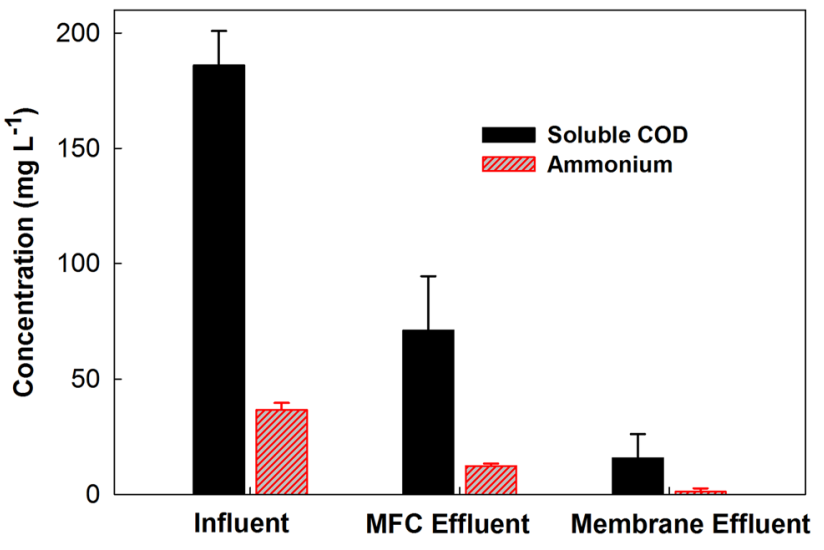

Fig. 3 The concentrations of soluble COD and ammonium nitrogen in the influent and effluent

presence of high $\mathrm{pH}$ of the catholyte and then driven out of the catholyte by liquid recirculation, which was supported by the fact that there was little ammonium $\left(<2 \mathrm{mg} \mathrm{N} \mathrm{L}^{-1}\right)$ detected in the catholyte. The membrane permeate contained about $2.5 \mathrm{mg} \mathrm{N} \mathrm{L}^{-1}$ of nitrate, which resulted from nitrification in the membrane photobioreactor where there were bacteria in addition to algae and dissolved oxygen produced by algae. Phosphorous, on the other hand, was not well removed in the system $(<15 \%$ removal efficiency). The concentration of total phosphate (TP) slightly decreased from 8.3 to $8.1 \mathrm{mg} \mathrm{P} \mathrm{L}^{-1}$ during the $\mathrm{MFC}$ treatment, and the membrane photobioreactor further reduced TP to $7.1 \mathrm{mg} \mathrm{P} \mathrm{L}^{-1}$.

In a membrane-based treatment system, transmembrane pressure (TMP) is a key parameter to reflect membrane fouling. The present system was operated for a constant flux of 5.5 LMH, and the TMP is expected to increase over time due to membrane fouling. Figure 4 shows the TMP variation in a period of 30 days. It took about 7 days for the TMP to increase from 10 to $35 \mathrm{kPa}$; after membrane cleaning, the TMP could decrease to $10-15 \mathrm{kPa}$. The TMP values were within the range of the recommended operational pressure $(<35 \mathrm{kPa})$, benefited from several factors: first, periodic membrane cleaning (using water rinse; no chemical cleaning was performed) is critical to maintain operational TMP; second, the MFC pretreatment removed a significant portion of organic compounds, thereby limiting the growth of heterotrophic bacteria and reducing the chance of production of foulants such as extracellular polymeric substances; and third, the present membrane photobioreactor adopted an attached growth mode, in which algae formed biofilm on the plate and glass wall, and the attached growth avoided a large amount of suspended biomass that could foul the membrane. Algal biomass was collected once a week, and $1.03 \pm 0.55 \mathrm{~g}$ of dry mass 


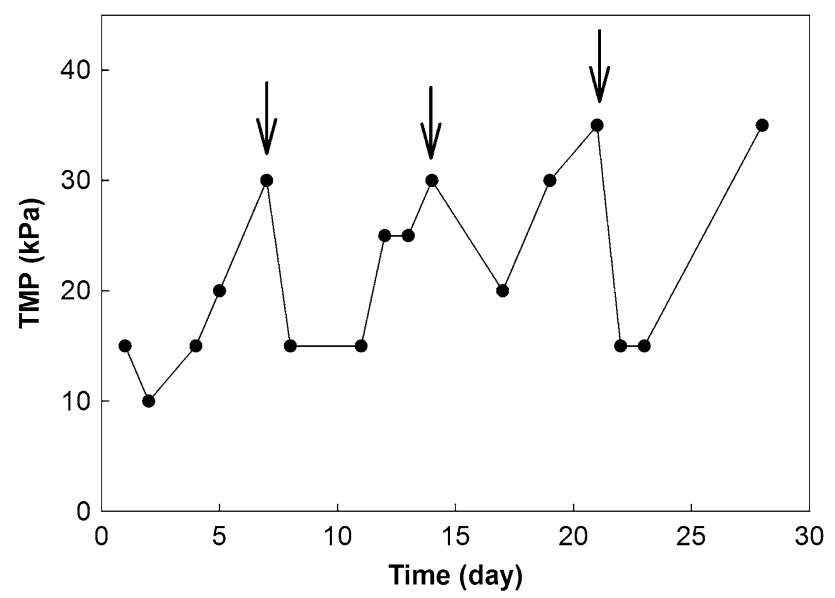

Fig. 4 The variation of transmembrane pressure (TMP) during the system operation. Arrows indicate the algal harvesting and membrane cleaning

could be obtained, equivalent to an algal concentration of $44.4 \pm 23.8 \mathrm{mg} \mathrm{L}^{-1}$ (based on the volume of the water that was treated within the sampling period).

When the HRT of the membrane photobioreactor was extended from 1.8 to 3.0 days by enlarging the liquid volume from 6 to $10 \mathrm{~L}$, the treatment performance was generally improved. The SCOD concentration in the membrane permeate was $7.5 \pm 4.2 \mathrm{mg} \mathrm{L}^{-1}$, representing nearly $96 \%$ removal. The concentrations of both ammonium and nitrate were below $1 \mathrm{mg} \mathrm{N} \mathrm{L}^{-1}$. The TP concentration was reduced to $6.4 \mathrm{mg} \mathrm{P} \mathrm{L}^{-1}$, more than $22 \%$ removal. At the water flux of 5.5 LMH, the TMP could be maintained under the maximum operational TMP with proper membrane cleaning and removal of contaminants by the MFCs and the photobioreactor. The weekly algal production was significantly increased to $3.10 \pm 0.30 \mathrm{~g}$ of dry mass, or $133.7 \pm 12.9 \mathrm{mg} \mathrm{L}^{-1}$. This improvement was likely related to the extended HRT, which allowed more removal of organic compounds and reduced the competition of heterotrophic bacteria with algae for nutrients.

\section{MFC loop operation}

In the prior experiments, the effluent from the MFC anodes would flow directly into the membrane photobioreactor and there was a separate liquid stream acting as a catholyte, which would create a need for additional water to operate the cathode. MFCs can also be operated in a loop mode, in which the anode effluent flows to the cathode [26, 33]. Herein, the loop mode of the operation was examined for the influence on the system performance. When the anode effluent flowed to the cathode, additional treatment of contaminants occurred on the cathode. The organic concentration in the cathode effluent (which was the influent to

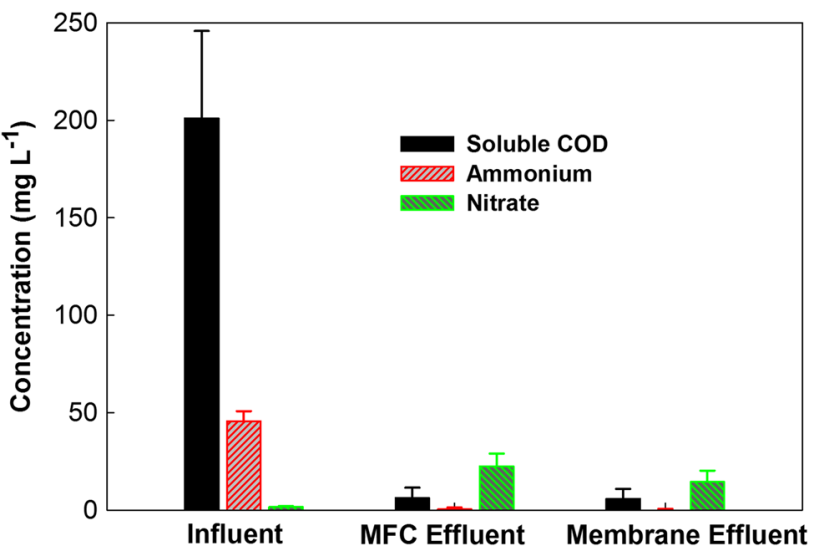

Fig. 5 The concentrations of soluble COD, ammonium nitrogen, and nitrate nitrogen in the influent and effluents from the MFC loop operation. "MFC effluent" means the effluent from the MFC cathode compartment

the membrane photobioreactor) was $6.2 \pm 5.4 \mathrm{mg} \mathrm{L}^{-1}$, representing $97 \%$ removal efficiency, and nearly $100 \%$ ammonium nitrogen was removed in the MFCs with an effluent concentration of $0.2 \pm 0.4 \mathrm{mg} \mathrm{N} \mathrm{L}^{-1}$ (Fig. 5). The nitrate concentration in the MFC effluent was $22.5 \pm 6.5 \mathrm{mg} \mathrm{N} \mathrm{L}^{-1}$, which then decreased to $14.5 \pm$ $5.8 \mathrm{mg} \mathrm{N} \mathrm{L}^{-1}$ in the membrane permeate (Fig. 5). Those results demonstrate that multiple microbial activities appeared on the MFC cathodes, including aerobic oxidation of organic compounds by heterotrophs, nitrification, and possible bioelectrochemical denitrification. These activities could compete with the cathode electrodes for oxygen (e.g., oxidation of organics and ammonia) or electrons (bioelectrochemical denitrification), but electricity generation was not negatively impacted and likely benefited from sufficient supply of oxygen.

However, algal biomass production significantly decreased to $57.1 \pm 8.5 \mathrm{mg} \mathrm{L}^{-1}$, which was possibly due to two reasons. First, the available nitrogen source was changed from ammonia to nitrate due to nitrification on the MFC cathode, and some algae may grow faster with ammonia than with nitrate [34]. Second, the catholyte $\mathrm{pH}$ increased after the MFC cathode and could create an unfavorable condition for the subsequent algal bioreactor. In the prior tests (non loop operation), the $\mathrm{pH}$ of the MFC anode effluent (which was the influent to the membrane photobioreactor) was 6.53-6.80, and the membrane permeate had $\mathrm{pH}$ of 7.17-7.50. Under the condition of the loop operation, the average $\mathrm{pH}$ of the MFC catholyte (which was the influent to the membrane photobioreactor) was 8.17 , and the average $\mathrm{pH}$ of the membrane permeate was 9.13. The $\mathrm{pH}$ shift towards an alkaline condition in the membrane photobioreactor could negatively influence algal growth [35]. 


\section{Energy production and consumption}

Energy production in the present system includes two parts, direct electricity generation from the MFCs and indirect electricity generation from algal biomass production (which can be converted to electricity). The direct electricity generation was normalized to the volume of the treated water, $\mathrm{kWh} \mathrm{m}^{-3}$ [31]. The indirect electricity generation was estimated with the assumption that biomass contains $40 \%$ oil that can be converted to biodiesel with $E_{\text {biodiesel }}$ of $\sim 37,800 \mathrm{MJ} \mathrm{t}^{-1}$ and conversion efficiency from diesel to electricity is $30 \%$ [17]. Energy consumption in the present system is mainly due to recirculation of the anolyte and the catholyte; the energy consumption by the feeding pump and the vacuum pump was significantly lower than that of recirculation and thus was not included [36]. As shown in Fig. 6, energy production/consumption was greatly affected by the experimental conditions (the conditions of three experiments, $\mathrm{A}, \mathrm{B}$, and $\mathrm{C}$ are explained in the caption of Fig. 6). The experiment A had a negative energy balance because of its more energy consumption $\left(0.172 \mathrm{kWh} \mathrm{m}^{-3}\right)$ than the production $\left(0.085 \mathrm{kWh} \mathrm{m}^{-3}\right)$; the high energy consumption was due to the catholyte recirculation $\left(0.094 \mathrm{kWh} \mathrm{m}^{-3}\right)$ and the anolyte recirculation $\left(0.078 \mathrm{kWh} \mathrm{m}^{-3}\right)$. The energy production was dominated by the indirect electricity generation from algal biomass $\left(0.062 \mathrm{kWh} \mathrm{m}^{-3}\right)$. When the HRT of the membrane photobioreactor increased to 3.0 days (experiment B), energy consumption by the system remained the same

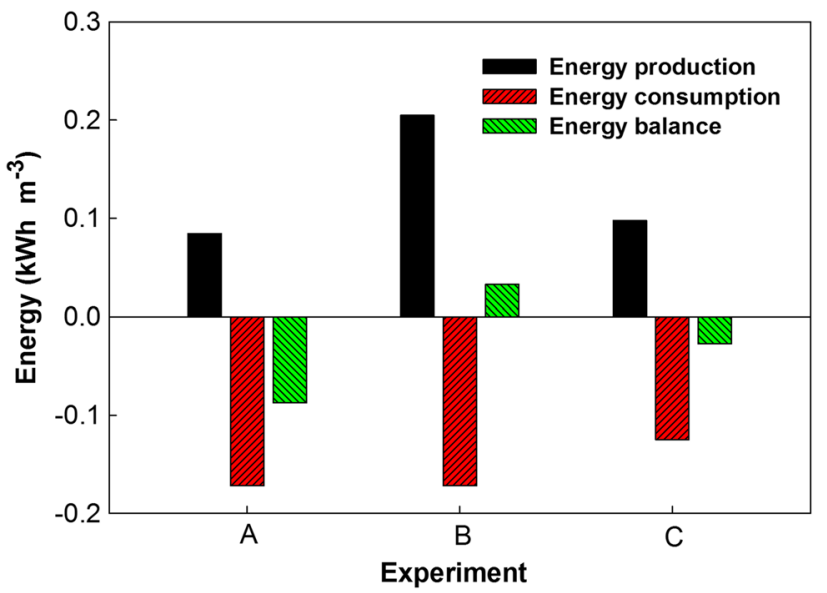

Fig. 6 Analysis of energy production, consumption, and balance under three experimental conditions. The data of energy consumption are presented in negative values for comparison purpose. Experiment $A$ : anolyte recirculation rate $200 \mathrm{~mL} \mathrm{~min}{ }^{-1}$, catholyte recirculation rate of $120 \mathrm{~mL} \mathrm{~min}^{-1}$, and photobioreactor HRT 1.8 days. Experiment $B$ : anolyte recirculation rate $200 \mathrm{~mL} \mathrm{~min}^{-1}$, catholyte recirculation rate of $120 \mathrm{~mL} \mathrm{~min}^{-1}$, and photobioreactor HRT 3.0 days. Experiment $C$ (loop operation): anolyte recirculation rate $200 \mathrm{~mL} \mathrm{~min}^{-1}$, catholyte recirculation rate of $60 \mathrm{~mL} \mathrm{~min}^{-1}$, and photobioreactor HRT 3.0 days as that of the experiment $\mathrm{A}$, but energy production significantly increased to $0.205 \mathrm{kWh} \mathrm{m}^{-3}$, because of the increased algal biomass production $\left(133.7 \mathrm{mg} \mathrm{L}^{-1}\right)$ resulting in more indirect electricity generation $\left(0.186 \mathrm{kWh} \mathrm{m}^{-3}\right)$. Under this condition, a positive energy balance of $0.033 \mathrm{kWh} \mathrm{m}^{-3}$ was achieved. The loop operation (experiment C), despite a HRT of 3.0 days in the photobioreactor, had lower algal biomass production and its total energy production of $0.098 \mathrm{kWh} \mathrm{m}^{-3}$ was lower than the previous experiment B. However, because of the reduced catholyte recirculation rate to $60 \mathrm{~mL} \mathrm{~min}^{-1}$, the energy consumption by the catholyte recirculation became lower at $0.047 \mathrm{kWh} \mathrm{m}^{-3}$, resulting in total energy consumption of $0.125 \mathrm{kWh} \mathrm{m}^{-3}$ by both recirculation pumps. This led to a less negative energy balance of $-0.027 \mathrm{kWh} \mathrm{m}^{-3}$ in the loop operation (experiment $\mathrm{C}$ ) than $-0.087 \mathrm{kWh} \mathrm{m}^{-3}$ of the experiment $\mathrm{A}$.
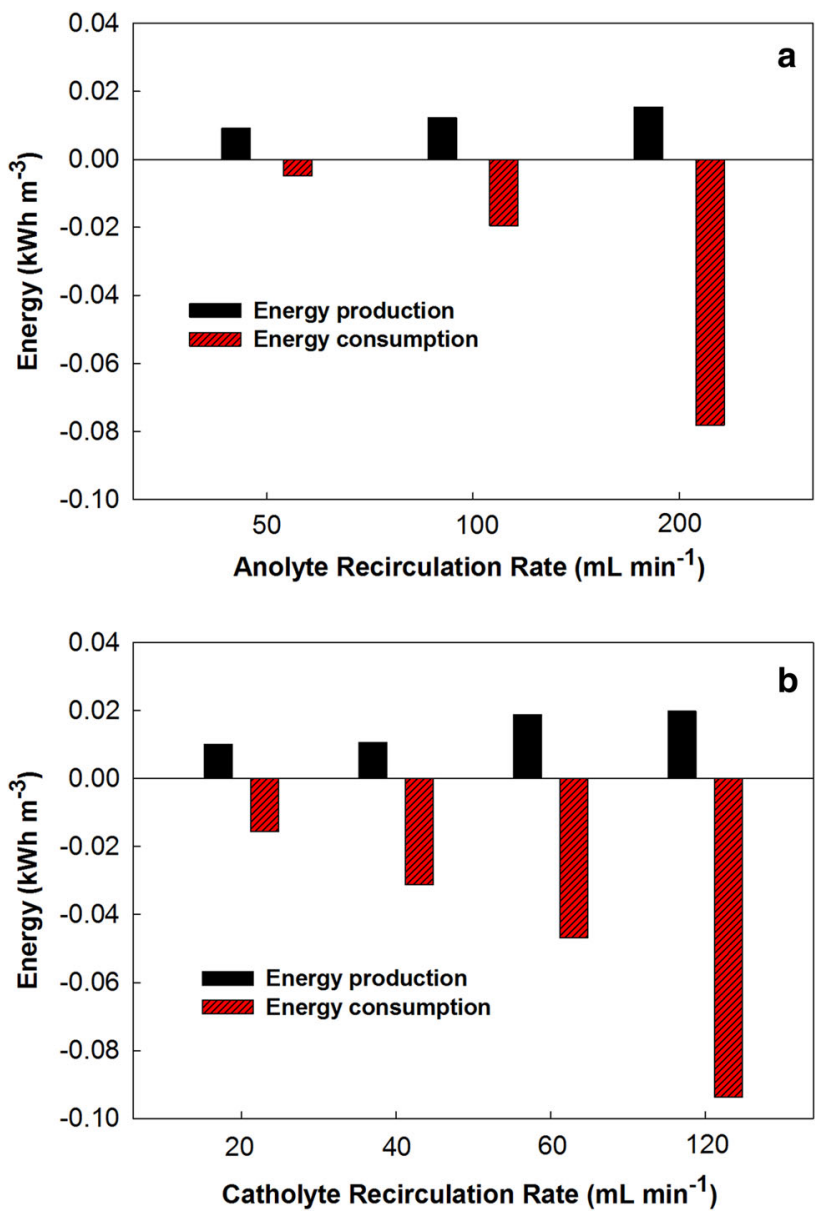

Fig. 7 The effects of the electrolyte recirculation rates on the MFC energy production and consumption under the loop-operation mode: a varying anolyte recirculation rates (while the catholyte recirculation

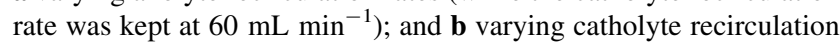
rates (while the anolyte recirculation rate was kept at $200 \mathrm{~mL} \mathrm{~min}^{-1}$ ) 
Considering the importance of the electrolyte recirculation rates to energy consumption, we further examined the energy consumption and production in the MFCs by varying the anolyte or the catholyte recirculation rates under the loop operation condition. Three anolyte recirculation rates, 50, 100 and $200 \mathrm{~mL} \mathrm{~min}^{-1}$, were studied while keeping the catholyte recirculation rate at

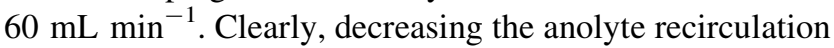
rate from 200 to $50 \mathrm{~mL} \mathrm{~min}^{-1}$ reduced the energy consumption from 0.078 to $0.005 \mathrm{kWh} \mathrm{m}^{-3}$, but energy production also dropped from 0.015 to $0.009 \mathrm{kWh} \mathrm{m}^{-3}$ (Fig. 7a). In the aspect of energy, a low anolyte recirculation rate would be more beneficial. The anolyte recirculation rate also influenced the SCOD concentration in the anolyte effluent, which increased from $11 \mathrm{mg} \mathrm{L}^{-1}$ (at $200 \mathrm{~mL} \mathrm{~min}^{-1}$ ) to $24 \mathrm{mg} \mathrm{L}^{-1}$ (at $50 \mathrm{~mL} \mathrm{~min}^{-1}$ ). Because of the additional COD removal on the cathode, such difference in the anolyte effluent COD was eliminated in the catholyte effluent (which was the influent to the membrane photobioreactor). A similar trend of energy consumption and production was obtained with varying the catholyte recirculation rates (Fig. 7b). In general, the catholyte recirculation consumed more energy than the anolyte recirculation. For example, the catholyte recirculation at $120 \mathrm{~mL} \mathrm{~min}^{-1}$ required $0.094 \mathrm{kWh} \mathrm{m}^{-3}$, higher than $0.078 \mathrm{kWh} \mathrm{m}^{-3}$ by the anolyte recirculation at $200 \mathrm{~mL} \mathrm{~min}^{-1}$. This is because the catholyte recirculation was conducted in an open environment, which resulted in a higher hydraulic head loss than that of the anolyte recirculation in a closed environment.

\section{Outlook}

The present system has a potential to become an alternative approach for energy efficient treatment of wastewater. Physically separating algal bioreactors from MFCs may offer more flexibility in system maintenance. For instance, working on one reactor (e.g., algal collection in the photobioreactor) will have less effect on the other (e.g., MFCs). However, this separation also creates more demand for footprint. Thus, the present system could be more suitable in an area where a large piece of land is available. Using photobioreactors for algal growth over the openpond approach may result in a smaller footprint, but its capital cost is also higher. Integrating membrane filtration in the photobioreactor will not only help separate algal biomass from the treated wastewater, but also enhance the quality of the final effluent. Although phosphate removal was not well accomplished, the membrane permeate may be used for agricultural irrigation (if there is such a need in an area adjacent to wastewater treatment facilities), which would allow the residue of valuable nutrients. The benefits of nutrients in irrigation will compete for nutrients with algal growth, and the tradeoff between the removal and uptake by algae will depend on the specific need or economic analysis. Loop operation did not seem to be beneficial, because of reduced algal production; a small portion of the membrane permeate may be used as the catholyte and the exact amount will need to be experimentally determined.

Further development of this system will need to address several issues. First, the energy production in the MFCs should be further improved, and this may be achieved by optimizing MFC configuration (to reduce internal resistance). Second, the energy consumption should be further reduced, and this could be accomplished by optimizing operating conditions such as the rate of electrolyte recirculation. Third, the photobioreactor used in this study was more like an "open pond" configuration, and in the future, enclosed photobioreactor systems will be of interest for improving algal production. Fourth, actual wastewater needs to be examined in this system for the effects of complex substrates and native microbes on the system performance.

\section{Conclusions}

A system coupling MFCs with a membrane photobioreactor has been demonstrated for effective removal of organic and nitrogen compounds from a synthetic wastewater. Bioenergy in the form of electricity and algal biomass (with further conversion) was harvested from the system. A longer HRT in the photobioreactor resulted in more production of algal biomass and also a larger footprint of the reactor. The use of hollow fiber membranes ensured the high quality of the final effluent and also helped to separate algal biomass for further collection. The system could potentially achieve a positive energy balance, under the condition of high production of algal biomass. Energy consumption may be reduced by optimizing the recirculation rates of both the anolyte and the catholyte. The results of this study encourage further investigation of the present system as an alternative approach for energyefficient wastewater treatment and using treated wastewater for algal cultivation.

Acknowledgments This work was financially supported by a grant from National Science Foundation (\#1358145). Shuai Luo was supported by a fellowship from Water INTERface IGEP, Graduate School of Virginia Tech.

\section{References}

1. Li W-W, H-q Yu, He Z (2014) Towards sustainable wastewater treatment by using microbial fuel cells-centered technologies. Energy Environ Sci 7:911-924 
2. Logan BE, Hamelers B, Rozendal RA, Schroder U, Keller J, Freguia S, Aelterman P, Verstraete W, Rabaey K (2006) Microbial fuel cells: methodology and technology. Environ Sci Technol 40:5181-5192

3. Pant D, Van Bogaert G, Diels L, Vanbroekhoven K (2010) A review of the substrates used in microbial fuel cells (MFCs) for sustainable energy production. Bioresour Technol 101:1533-1543

4. Wang X, Cai Z, Zhou Q, Zhang Z, Chen C (2012) Bioelectrochemical stimulation of petroleum hydrocarbon degradation in saline soil using U-tube microbial fuel cells. Biotechnol Bioeng 109:426-433

5. Kondaveeti S, Lee SH, Park HD, Min B (2014) Bacterial communities in a bioelectrochemical denitrification system: the effects of supplemental electron acceptors. Water Res 51:25-36

6. Zhang Y, Angelidaki I (2015) Recovery of ammonia and sulfate from waste streams and bioenergy production via bipolar bioelectrodialysis. Water Res 85:177-184

7. Zhang Y, Angelidaki I (2015) Counteracting ammonia inhibition during anaerobic digestion by recovery using submersible microbial desalination cell. Biotechnol Bioeng 112:1478-1482

8. Kelly P, He Z (2014) Nutrients removal and recovery in bioelectrochemical systems: a review. Bioresour Technol 153:351-360

9. Cai T, Park SY, Li Y (2013) Nutrient recovery from wastewater streams by microalgae: status and prospects. Renew Sustain Energy Rev 19:360-369

10. Christenson L, Sims R (2011) Production and harvesting of microalgae for wastewater treatment, biofuels, and bioproducts. Biotechnol Adv 29:686-702

11. Xiao L, He Z (2014) Applications and perspectives of phototrophic microorganisms for electricity generation from organic compounds in microbial fuel cells. Renew Sustain Energy Rev 37:550-559

12. Velasquez-Orta SB, Curtis TP, Logan BE (2009) Energy from algae using microbial fuel cells. Biotechnol Bioeng 103:1068-1076

13. Campo AGd, Cañizares P, Rodrigo MA, Fernández FJ, Lobato J (2013) Microbial fuel cell with an algae-assisted cathode: a preliminary assessment. J Power Sources 242:638-645

14. He H, Zhou M, Yang J, Hu Y, Zhao Y (2014) Simultaneous wastewater treatment, electricity generation and biomass production by an immobilized photosynthetic algal microbial fuel cell. Bioprocess Biosyst Eng 37:873-880

15. Kakarla R, Min B (2014) Evaluation of microbial fuel cell operation using algae as an oxygen supplier: carbon paper cathode vs. carbon brush cathode. Bioprocess Biosyst Eng 37:2453-2461

16. Zhang Y, Noori JS, Angelidaki I (2011) Simultaneous organic carbon, nutrients removal and energy production in a photomicrobial fuel cell (PFC). Energy Environ Sci 4:4340-4346

17. Xiao L, Young EB, Berges JA, He Z (2012) Integrated photobioelectrochemical system for contaminants removal and bioenergy production. Environ Sci Technol 46:11459-11466

18. Xiao L, Young EB, Grothjan JJ, Lyon S, Zhang H, He Z (2016) Wastewater treatment and microbial community in an integrated photo-bioelectrochemical system affected by different wastewater algal inocula. Algal Res 12:446-454

19. Molina Grima E, Belarbi EH, Acien Fernandez FG, Robles Medina A, Chisti Y (2003) Recovery of microalgal biomass and metabolites: process options and economics. Biotechnol Adv 20:491-515

20. Cogne G, Cornet JF, Gros JB (2005) Design, operation, and modeling of a membrane photobioreactor to study the growth of the Cyanobacterium Arthrospira platensis in space conditions. Biotechnol Prog 21:741-750

21. Honda R, Boonnorat J, Chiemchaisri C, Chiemchaisri W, Yamamoto K (2012) Carbon dioxide capture and nutrients removal utilizing treated sewage by concentrated microalgae cultivation in a membrane photobioreactor. Bioresour Technol 125:59-64

22. Cheng L, Zhang L, Chen H, Gao C (2006) Carbon dioxide removal from air by microalgae cultured in a membrane-photobioreactor. Sep Purif Technol 50:324-329

23. Gao F, Yang ZH, Li C, Wang YJ, Jin WH, Deng YB (2014) Concentrated microalgae cultivation in treated sewage by membrane photobioreactor operated in batch flow mode. Bioresour Technol 167:441-446

24. Gao F, Yang ZH, Li C, Zeng GM, Ma DH, Zhou L (2015) A novel algal biofilm membrane photobioreactor for attached microalgae growth and nutrients removal from secondary effluent. Bioresour Technol 179:8-12

25. Praveen P, Loh KC (2016) Nitrogen and phosphorus removal from tertiary wastewater in an osmotic membrane photobioreactor. Bioresour Technol 206:180-187

26. Zhang F, Ge Z, Grimaud J, Hurst J, He Z (2013) Long-term performance of liter-scale microbial fuel cells installed in a municipal wastewater treatment facility. Environ Sci Technol 47:4941-4948

27. Li J, Zhu Y, Zhuang L, Otsuka Y, Nakamura M, Goodell B, Sonoki T, He Z (2015) A novel approach to recycle bacterial culture waste for fermentation reuse via a microbial fuel cell-membrane bioreactor system. Bioprocess Biosyst Eng 38:1795-1802

28. Zhang B, Wen Z, Ci S, Mao S, Chen J, He Z (2014) Synthesizing nitrogen-doped activated carbon and probing its active sites for oxygen reduction reaction in microbial fuel cells. ACS Appl Mater Interfaces 6:7464-7470

29. Angenent LT, Sung S (2001) Development of anaerobic migrating blanket reactor (AMBR), a novel anaerobic treatment system. Water Res 35:1739-1747

30. Ge Z, Li J, Xiao L, Tong Y, He Z (2014) Recovery of electrical energy in microbial fuel cells. Environ Sci Technol Lett $1: 137-141$

31. Xiao L, Ge Z, Kelly P, Zhang F, He Z (2014) Evaluation of normalized energy recovery (NER) in microbial fuel cells affected by reactor dimensions and substrates. Bioresour Technol 157:77-83

32. Kim J, Kim K, Ye H, Lee E, Shin C, McCarty PL, Bae J (2011) Anaerobic fluidized bed membrane bioreactor for wastewater treatment. Environ Sci Technol 45:576-581

33. Clauwaert P, Mulenga S, Aelterman P, Verstraete W (2009) Litre-scale microbial fuel cells operated in a complete loop. Appl Microbiol Biotechnol 83:241-247

34. Dortch Q (1990) The interaction between ammonium and nitrate uptake in phytoplankton. Mar Ecol Prog Ser 61:183-201

35. Park JBK, Craggs RJ, Shilton AN (2011) Wastewater treatment high rate algal ponds for biofuel production. Bioresour Technol 102:35-42

36. Jacobson KS, Kelly P, He Z (2015) Energy balance affected electrolyte recirculation and operating modes in microbial fuel cells. Water Environ Res 87:252-257 